\title{
Myxoid Changes Present
}

National Cancer Institute

\section{Source}

National Cancer Institute. Myxoid Changes Present. NCI Thesaurus. Code C39744.

A morphologic finding indicating the presence of myxoid changes in a tissue sample. 